\title{
GARDEN OWNERSHIP AS A SOLUTION TO FOOD INSECURITY IN URBAN AREAS OF SOUTH AFRICA: CASE OF FOOD GARDENS IN ALICE TOWN, EASTERN CAPE PROVINCE
}

\author{
Bongiwe Mcata ${ }^{\bowtie}$ \\ Africa Institute of South Africa (AISA), South Africa
}

\begin{abstract}
Programs like Siyazondla Homestead Gardens, Siyakhula and Massive Food Production Program were introduced by the provincial government of the Eastern Cape province with the aim of improving household food production, nutrition and food security. However, full ownership of food gardens by households has been a challenge. Thus, this paper investigates the factors influencing the ownership of home gardens by Alice Town households. Households in Alice Town, Eastern Cape province were purposively selected for data collection, and a structured questionnaire was employed. A binary logistic regression model was adopted to determine the factors that influence food gardens ownership among the sampled households. Results show that three variables that influenced food gardens ownership were location, land access and education level. These variables had a significance level of $5 \%$. The paper concludes that having access to food gardens by city dwellers can help improve their food security status. However, owning a garden is a challenge due to the variables highlighted. Thus, it is important to promote associations in urban areas and provide training and workshops that can improve the productivity of home garden owners. This is how access to better nutrition and safe, rich and fresh vegetables can be achieved.
\end{abstract}

Keywords: food gardens, poverty, food security, Eastern Cape province

\section{INTRODUCTION}

In African countries, the issue of "No poverty" (SDG1) and "Zero hunger" (SDG2) are crucial aspects being currently fought for due to slow development and lack of resources these countries face. Thus, they tend to be vulnerable to many things such as high level of poverty, unemployment and lack of economic development. Agriculture has been the only coping strategy that has been employed to combat poverty, and it has been mostly relied upon in rural areas. Urban areas (or cities) are areas where no one would consider practicing agriculture because they are linked with industrialization rather than with agricultural processes. However, due to the rising number of people who have migrated from rural to urban areas in search of better standards of living and employment opportunities, the issue of poverty and food insecurity comes to life. According to Baiphethi and Jacobs (2009), food insecurity affects the urban poor more severely as they are mostly dependent on the market in most sub-Saharan Africa, unlike their rural counterparts who are able to exploit natural resources to provide for food or to generate income.

During the 1996 World Food Summit, it was agreed that food security would occur when all people have access to sufficient, nutritionally adequate and safe food at all times for an active and healthy life (FAO, 1996).

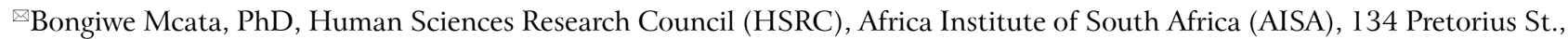
0001 , Pretoria, South Africa, e-mail: bmcata@hsrc.ac.za; https://orcid.org/0000-0002-6066-4007
} 
Baiphethi and Jacobs (2009) mention that food insecurity occurs at four different levels, namely: the national level, regional level, community level and household level. While South Africa is a country known to be food secure at the national level, food insecurity does exist at the household level (Gichunge and Kidwaro, 2014). In addition, on a broader scope, food security may be defined as the ability of people to receive enough food for living, and as achieving the following four pillars: food access, food availability, food utilization and stability (Mcata, 2013).

Nonetheless, poverty and food insecurity remain a major issue which resulted in the identification of strategies such as food gardens that can alleviate poverty within urban areas (UNISDR, 2015). Thus, the growth of urban areas results in great demand for food supply. Tacoli et al. (2015) define urban areas as areas to which rural people tend to migrate and settle in, searching for better standards of living. According to Rubin (2011), urban dwellers have been vulnerable to many issues such as poverty, climate change and disaster risks. Thus, Mcata (2013) states that home gardens are highly vital in providing household income and food throughout the year through different crops that can be grown and harvested at a different time. As a result, own food production by households has been one of the major ways of improving food insecurity (FAO, 2018).

Home gardens have become more than just about the production of food, they also fulfill a social function (FAO, 2012; Baiyegunhi, 2014). Studies throughout the world have been conducted with the hope of identifying ways of improving food insecurity. For example, a study conducted by Tynsong and Tiwari (2010) in Indonesia and Nicaragua showed that home gardens play a significant role in their livelihood with a contribution of $21.1 \%$ and $35 \%$ to household total income, respectively. Hence, own food production through food garden ownership has been identified to have great potential in dealing with the food insecurity challenge in both urban and rural areas. Thus, urban agriculture came into existence.

The adoption of agricultural practice by urban dwellers is termed urban agriculture. FAO (2018) defines urban agriculture as an agricultural activity that allows households to have access to "fresh food, generates employment, recycles urban wastes, creates greenbelts, and strengthens cities' resilience to climate change." However, food gardens have been the ones most suitable for urban areas due to limitations such as land access and costly water usages, just to mention a few.

There are three types of food gardens that tend to be promising to urban dwellers, namely: home gardens, school gardens and community gardens (Sanyé-Mengual et al., 2015). These gardens are said to provide a vital source of food and nutrition to urban households. Gichunge and Kidwaro (2014) noted that home gardens provide the households with direct access to a diversity of nutritionally rich foods, including roots, tubers, green leafy vegetables, condiments, nuts, legumes, fruits and livestock products. Furthermore, this practice is there to supplement the household food production system (Bagson and Wuleka Kuuder, 2013). Thus, great benefits are linked with home gardens because they have established a traditional way of providing food and offer great potential for improving household food security while alleviating poverty. Therefore, the purpose of this paper is to investigate the factors that influence the ownership of home gardens by urban households in Alice Town, Eastern Cape province, given that food gardens are associated with huge benefits.

\section{LITERATURE REVIEW: FOOD SECURITY STATUS OF EASTERN CAPE PROVINCE}

Sustainable Development Goals (SDGs) reflect the efforts made to meet the African challenges; the key goals are to end poverty in all forms everywhere (SDG1) and to combat hunger by improving the food security status. One way to achieve this is through sustainable agriculture (SDG2). Therefore, ownership of home gardens is one of the coping strategies that can be used to combat food insecurity and poverty in the Eastern Cape province that best fit the two SDGs referred to above. Food insecurity reduction in South African households is a major concern. Studies on the challenges of food insecurity and the contribution made by home gardens to improving household food security in the Eastern Cape have been conducted by scholars such as Seti (2003); Monde et al. (2006); Mcata (2013) and Matebeni (2018). Urban food insecurity is one of the problems faced by this province; it originates from high unemployment rates among household members and limited opportunities for households to generate income (Mtolo, 2016). In this province, the tool that has been most suitable and mostly used to measure household food status is the Poverty Line. 
As highlighted in the Stats SA (2017) report, after 2011, there has been a nationwide increase in the number of people (from 11 million to 13.8 million) living below the 2015 poverty line of ZAR 441 per person per month. These high poverty and unemployment rates result in great pressure to social grants. Hence, there is a dependency on it. The reason for high levels of poverty is the large number of households that are considered "poor" due to low income earned while having many dependants (Drimie and Ruysenaar, 2010). Therefore, the ability to earn cash and the prices of food are the two crucial components affecting household food security in urban areas.

According to Statistics South Africa (Stats SA), (2017), the Eastern Cape province and Limpopo province are the two main provinces in the country (South Africa) that have been highlighted to have the most vulnerable persons to poverty and food insecurity. Children (aged 17 and below), women and black Africans residing in rural areas of these provinces are victims of poverty and food insecurity. These provinces have both a rural and an urban population; hence, the problem of food insecurity does occur in both their rural and urban areas. The provinces face food insecurity crises since poverty is a challenge that cannot be ignored due to many factors such as unemployment, illiteracy problems, and the fact that most households are solely female-headed (Drimie and Ruysenaar, 2010). Therefore, a coping strategy to combat food insecurity is needed, and home gardens tend to be better solutions for these provinces since they both have great agricultural potential.

As highlighted in the Rural Development and Agrarian Reform (RDAR, 2016), Eastern Cape is the second largest province and is home to ca. $12.6 \%$ of the nation's population. Most of them (70\%) tend to reside in rural areas while others are found in urban and peri-urban areas (Young, 2013). Eastern Cape province is said to be roughly the size of Uruguay with a land area of about 168,966 km², and accounts for ca. 13\% of South Africa's total land area (Young, 2013). As mentioned earlier, the province deals with a high rate of poverty and unemployment which is about $48.1 \%$. This makes it vulnerable to food insecurity and poverty. Thus, there is a huge pressure to access funds so that households can be able to buy food. Social grants have been identified to be the most used source of income for these poor households.
Drimie and Ruysenaar (2010) note that dependence on social grants and migrants' remittance tend to be the only thing that protects these households from poverty and food insecurity. Therefore, home gardens could make a significant contribution towards enhancing household food security by supplementing household food baskets, providing income, employment and other specific benefits.

In the Eastern Cape province, home gardening is identified as the best promising strategy to help cope with food insecurity for these households, as evidenced by success stories from many countries and other South African provinces. For example, Cape Town and Johannesburg are the major South African cities where this practice has worked well, given that there are many successful home gardens projects. Therefore, this is one of the best coping strategies identified for this province due to its great potential in agricultural activities (RDAR, 2016).

Food production in urban areas is one of the vital aspects in making sure there is enough food for the local households; this is how poverty can be alleviated. There are many benefits from home gardens, such as access to fresh fruit and vegetables; income generation; empowerment of women; some form of exercise (recreation); reduction of grocery expenditure; healthy organic produce sold cheaper since there are no transportation costs encountered when marketed; and improvement in living conditions for the communities. Therefore, with the increasing population and food crisis, gardens can provide many people with improved livelihoods (FAO, 2012). Moreover, home gardens give instant access to fresh produce and limit the chances of households going to the market to buy vegetables. It can also help to save money on food because it would not be necessary to buy everything (Agbodigi and Adolor, 2014).

Home gardens also get to uplift the status of women. Women have been acknowledged to be the ones championing the practice of home gardens. The participation in and responsibilities of home gardening (including land preparation, planting, weeding, harvesting and marketing) vary across cultures. Hence, home gardens have a successful history of alleviating poverty and enhancing household food security. Therefore, constraints to ownership of home gardening that serves as a significant contributor towards poverty alleviation need to be identified so that proper solutions can be provided. 


\section{MATERIAL AND METHODS}

\section{Study area description}

Alice Town is one of the 7 major towns under the Raymond Mhlaba Local Municipality which is part of the Amathole District Municipality in the Eastern Cape province, as shown in Figure 1. Raymond Mhlaba local municipality came to life from an amalgamation that took place on August 3, 2016 between Nkonkobe local municipality and Nxuba local municipality (Stats SA, 2017). This is the largest of the 6 local municipalities in the Amathole district. The majority of the municipality's population reside in rural areas while others live in urban areas. Alice Town is one of the towns within this municipality that has a high level of urbanization. These rural areas are where most of the farming activities are being practiced on a small-scale basis, thus contributing to economic growth of the area (Stats SA, 2017).

\section{Study sampling}

This study was based on a sampling technique with a large population of $n \geq 30$. Non-probability sampling was done whereby purposive sampling was employed in this study. A sample of 60 households were interviewed $(n=60)$. The sample comprises of households that took part in home gardening but no longer own gardens. Thus, identifying factors that influenced the ownership of home gardens by these households was investigated in the study.

\section{Data collection}

A cross-sectional research design was employed when conducting this study. This allowed the researcher to carry out a survey with a structured questionnaire prepared to collect primary data. Data was collected to identify the factors influencing the ownership of home gardens. This process took place within a two-week period in July 2017. Furthermore, observations were done which helped in the write-up process. Xhosa and English were the languages used when collecting data. However, Xhosa was dominantly used when collecting data from these households so that the respondents can be able to understand and also express themselves easily.

\section{Data analysis description}

Primary data collected was coded and imported from excel into SPSS for analysis. Both descriptive and inferential analyses were employed in this study. The descriptive analysis was done, and a frequency table with percentages was used to profile the respondents. Also, inferential data analysis was employed whereby a relationship between variables was identified through regression analysis. In this case, the researcher wanted

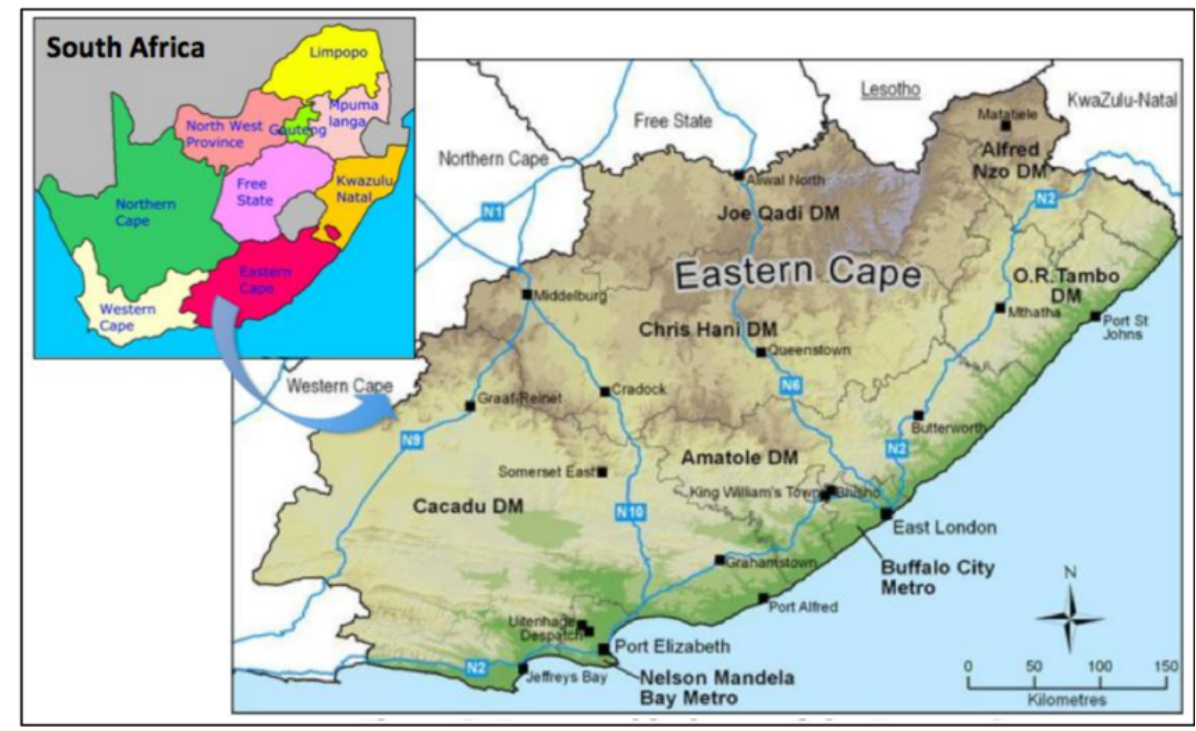

Fig. 1. South Africa - Eastern Cape Province Map Source: Google Maps, 2019. 
to identify the variables that influenced home garden ownership by households at Alice Town, and therefore a binary regression model was also used.

\section{Specification of the binary regression model}

According to Kleinbaum (1994), there are two main reasons for using logistic regression in economics research. Firstly, the logistic model imposes threshold and interaction effects and allows for the examination of social interaction (Montshwe, 2006). The logistic function is also extremely flexible and easily applicable, and the interpretation of the results is straightforward and meaningful.

Following Gujarati (2003), the cumulative logistic distribution function for factors that influence the ownership of home gardens by urban households was specified as:

$$
P=\frac{1}{1+e^{-Z}}
$$

Where $P$ was the probability of owning a home garden and $Z$ is a function of $m$ explanatory variables $(X)$, expressed as:

$$
Z=B_{0}+B_{1} X_{1}+B_{2} X_{2}+\ldots \ldots \ldots \ldots \ldots B_{m} X_{m}
$$
by:

The probability of owning a home garden was given

$$
1-P=\frac{1}{1-e^{Z}}
$$

The conditional probability of the outcome variable follows a binomial distribution with the probability given by the conditional means $P_{(i)}$. The logistic model in terms of logs is:

$$
\log \left(\frac{p}{1-p}\right)=\beta_{0}+\beta_{1} X_{1}+\beta_{2} X_{2}+\ldots+\beta_{k} X_{k}
$$

where $\log \left(\frac{p}{1-p}\right)=Z$

The log of odds ratio is not only linear in $X$ but also linear in the $B i$ variable. As a consequence, OLS is used. Taking the stochastic term $\mu$ into account, the logit econometric model to be used will be:

$$
Z=B_{0}+B_{1} X_{1}+B_{2} X_{2}+\ldots \ldots \ldots \ldots \ldots B_{m} X_{m}+\mu
$$

This econometric (logistic regression) model was used for the potential variables which are assumed to

\begin{tabular}{|c|c|c|}
\hline Variable name & $\begin{array}{c}\text { Type of } \\
\text { measurement }\end{array}$ & $\begin{array}{l}\text { Priori expecta- } \\
\text { tions }(+/-)\end{array}$ \\
\hline \multicolumn{3}{|l|}{ Dependent variable } \\
\hline \multicolumn{3}{|l|}{ home garden ownership } \\
\hline \multicolumn{3}{|l|}{ Independent variables } \\
\hline location & Dummy & + \\
\hline $\begin{array}{l}\text { gender (who owns and } \\
\text { maintains the garden) }\end{array}$ & Dummy & $+/-$ \\
\hline age (years) & Continuous & + \\
\hline $\begin{array}{l}\text { level of education (years - } \\
\text { assist with understanding } \\
\text { improved technology) }\end{array}$ & Continuous & + \\
\hline $\begin{array}{l}\text { household size } \\
\text { (number of members) }\end{array}$ & Continuous & $+/-$ \\
\hline Total income & Continuous & + \\
\hline Land access (Yes/No) & Dummy & + \\
\hline
\end{tabular}
affect home garden ownership in Alice Town. In this analysis, the dependent variable was home garden
Table 1. Variables used in the binary logistic regression model for home garden ownership

Source: own elaboration based on research.

ownership (home garden owned $=1$ or home garden not owned $=0$ ) as explained in the above equation. Potential independent variables which may influence home garden ownership were obtained from the literature review (Tynsong and Tiwari, 2010). The independent variables included in the model were location (rural or urban), education level, gender, age, households size, land access and total income, as shown in Table 1.

\section{RESULTS}

The study results are presented in two ways (descriptive and inferential) because so was the analysis, as highlighted in the corresponding section. The descriptive results included the demographic profiling of the respondents whereas the binary regression model was developed to identify the factors that influence home garden ownership by these households.

\section{Descriptive results}

The descriptive results present the various household socioeconomic variables of the sixty households used in this study. These variables are gender of household head, household size range, dominant households' age, 
education status of households, vegetable sources and home garden food usage. These are important aspects obtained from the respondents in understanding their arguments regarding the issues of poverty alleviation and the coping strategies (home garden ownership) that the households can use to deal with such a challenge.

As shown in Table 2, 48\% of the households visited are male-headed while $52 \%$ are female-headed. This revealed that women were more dominant in home garden ownership than men. This is because women were forced to be household heads while their husbands were compelled to go to the cities to do wage labor in the mines during the apartheid era (Matebeni, 2018).

As shown in the Table, most households visited have 5 to 8 members (42\%), while those with 9 or more members form the smallest group (26\%). The dominant respondents' household age range group is $61-70$ years $(58 \%)$, followed by the age range group of $51-60$ years

Table 2. Descriptive results of the study

\begin{tabular}{llc}
\hline \multicolumn{2}{c}{ Variables } & $\begin{array}{c}\text { Percentage of 60 Alice } \\
\text { Town households (\%) }\end{array}$ \\
\hline $\begin{array}{ll}\text { Gender of house- } \\
\text { hold head }\end{array}$ & male & 48 \\
Household size & $1-4$ & 52 \\
range & $5-8$ & 32 \\
& +9 & 42 \\
Dominant house- & $41-50$ years & 26 \\
hold age & $51-60$ years & 26 \\
& $61-70$ years & 16 \\
Education status of & none & 58 \\
household & primary & 16 \\
& secondary & 25 \\
& tertiary & 38 \\
Vegetable sources & urban markets & 21 \\
& own food & 85 \\
Home garden food & consumed & 15 \\
& sold & 60 \\
\hline
\end{tabular}

Source: own elaboration based on research.
$(16 \%)$. These are individuals who are retired, unemployed, pensioners, housewives and self-employed. As they stay home, they have more time to work the land compared to young and employed people who face time limitations. These findings suggest that home gardens are dominated by the elderly since the age of the households is likely to indicate the farming experience and may improve exposure to farming practices. However, this negatively affects the practice of home gardening since these old people have health problems such as blood pressure, diabetics, arthritis and other illnesses which restrict them from engaging in home gardening (Mcata, 2013). Therefore, this results in vulnerability to food insecurity.

Households with a secondary education are the largest group (with 38\%), followed by households with a primary education $(25 \%)$. Tertiary education was reported by $21 \%$ of households while $16 \%$ of the respondents did not have any formal education. Thus, it expected that the more educated a household head is, the better the household home garden can be managed; and the better the produce harvested from it; and the easier it is to adopt improved technologies that can enhance productivity and arability of the land used.

$85 \%$ of the respondents buy vegetables from urban markets, while $15 \%$ produce their own vegetables. This shows great dependency on purchased food which contributes to food price inflation as highlighted by Mcata (2013) citing Baiphethi and Jacobs (2009). Therefore, households who produce their own food get to reduce house expenditure and are cushioned from food price shocks. The majority of the respondents consumed what they produced $(60 \%), 35 \%$ stated that they sell some of what they harvest to their neighbors, and $15 \%$ donate to nearby preschools, church elders and others who are in need.

In order for the households to purchase basic necessities, including food, they need to have access to more disposable income. Thus, the inability of having income contributes to household food insecurity (Ferdous, 2016). Figure 2 shows the households' total monthly incomes, with three income intervals identified in this study, namely: 500-1000, 1001-2000 and $>2000$. The results show that most respondents are in the 1001-2000 income interval (60\%) while $37 \%$ earn more than 2000 and $30 \%$ are in the 500-1000 interval. Thus, access to a home garden helps improving food security of the household since they will get to reduce their expenditure. Also, growing own vegetables is 


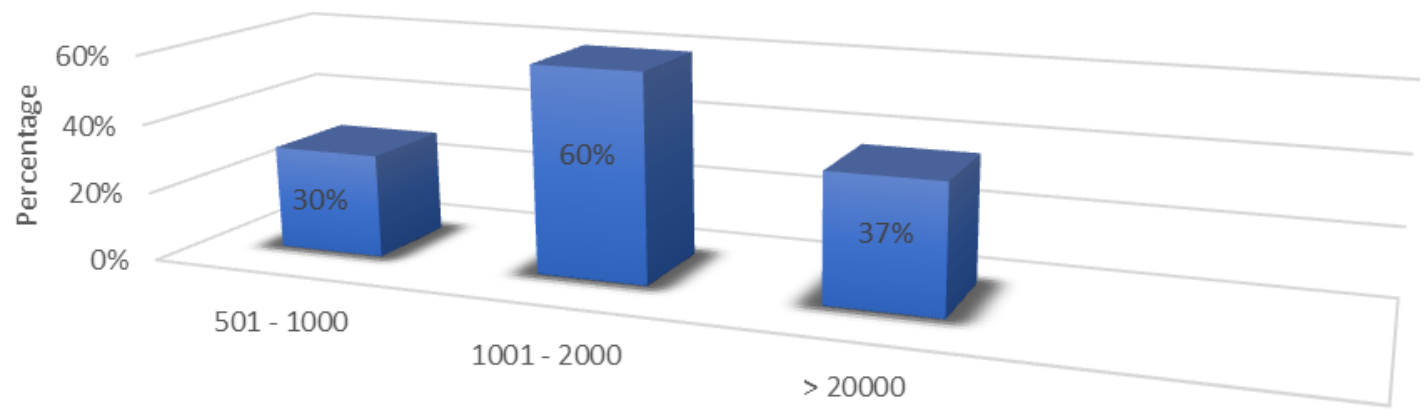

Household total income Range

Fig. 2. Household total income range

Source: own elaboration based on research.

a way to supplement the household's income through selling (Mcata, 2013).

The households' sources of income are essential for building up income. There is significant reliance on social grants due to the large scale of poverty, unemployment and economic downturn in South Africa. Social grants considerably contribute to household income, as highlighted in the above section (motivation for home gardening in Eastern Cape province). Figure 3 shows the different sources of household income. Most respondents depend on their salaries and wages for income $(36 \%)$ while $23 \%$ have old-age pensions as their source of income; $17 \%$ of the respondents have child grants as their main contributing source of income, and other $17 \%$ depend on their retirement pensions. This shows that owning a garden can help take a bit of pressure off the household income in terms of food to buy (especially vegetables).

\section{Empirical results}

As mentioned in the data analysis section, the factors that influence the ownership of home gardens by households were assessed with the use of a binary logistic regression model. Variables included in the model include location, gender, age, education level, household size, total income and land access. Out of these variables, three were significant at $5 \%$, as indicated in Table 3, while others were not significant.

Based on the results in Table 3, all three of the variables that are significant to home garden ownership

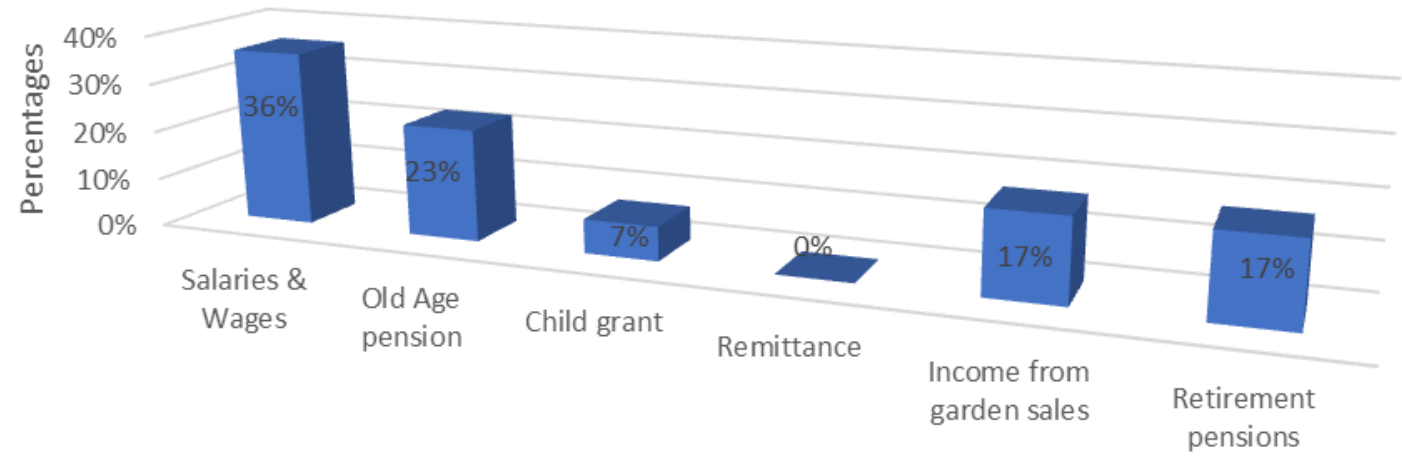

Sources of Income

Fig. 3. Household sources of income

Source: own elaboration based on research. 
Table 3. Factors affecting home garden ownership

\begin{tabular}{lcccc}
\hline \multicolumn{1}{c}{ Variable } & $\beta$ & S.E & Wald & Sig. \\
\hline Constant & 0.000 & 0.158 & 0.000 & 1.000 \\
Location & $1.452^{*}$ & 0.451 & 9.942 & 0.002 \\
Gender & -0.533 & 0.430 & 1.533 & 0.216 \\
Age & -0.039 & 0.484 & 0.006 & 0.936 \\
Level of education & $0.785^{*}$ & 0.244 & 10.361 & 0.001 \\
Household size & 0.128 & 0.569 & 0.050 & 0.822 \\
Total income & 0.000 & 0.000 & 0.979 & 0.322 \\
Land access & $1.078^{*}$ & 0.448 & 5.780 & 0.016 \\
\hline
\end{tabular}

* 5\% significance level, Nagelkerke R Square $=0.474$, Cox \& Snell R Square $=0.356$, Log likelihood value $=151.500$. Source: own elaboration based on research.

have positive coefficients. 'Household location' refers to whether a household is located in a rural or an urban area. Rural households stand a better chance of owning a home garden than those in urban areas because land in urban areas is limited and that which is available tends to be used for non-agricultural purposes.

Location affects the practice of home gardens since people residing in rural areas have different perspectives about the importance of home gardening than people from urban areas. Unlike urban dwellers, the rural population tend to practice home gardening as a culture and to utilize the land they own. Thus, land is an essential resource and does not only serve as a major source of food but also works as a source of social identity. This is especially true for the African people whose identity is mainly based on culture and beliefs (Mcata, 2013).

The level of education is positively related to home garden ownership, as indicated by its coefficient (0.785). This means that an additional year of schooling is expected to result in a $0.7 \%$ increase in participation in home gardening. These findings are in line with Muchara (2010) who holds that the level of education increases the chances for a person to own a garden and achieve household food security. Education can mean a person is exposed to information on the essentialities and benefits associated with home garden ownership (i.e. access to fresh vegetables, reduced expenditure, generation of income from selling to neighbors, etc.). Ashby (1981), as cited by Mcata (2013), agrees with the foregoing by stating that better education of farmers and their children will make them able to choose and apply sound farming innovations and modern farming methods within a sustainable context. Therefore, households with literate people tend to engage in home gardening since they know the importance and role of home gardens to their households.

Access to land was also a significant variable. Land is said to be a primary means of subsistence and income generation, especially in rural economies. Also, land has multiple uses and it is expected that there will be disagreements regarding the ownership and usage of land amongst different individuals. Mqikela (2014) indicated that access to land enables rural inhabitants to put their time and labor to productive use in farming activities. It also assists the households by providing them with a supplementary source of livelihoods for rural workers and for the rural poor. Hence, urban people also get to benefit from what is produced from the land because poverty does not affect only rural people but also those residing in urban areas.

\section{CONCLUSION AND RECOMMENDATIONS}

In conclusion, home garden ownership has been identified to be a good strategy for coping with poverty and food insecurity, especially amongst households with low income. Research on the success and importance of home gardens has been conducted, as highlighted in the previous sections, throughout two South African provinces. 
However, there are constraints that need to be considered which prevent the success of home garden ownership as identified in the study, namely: access to land, location and level of education. Of the constraints mentioned, land access is the major barrier since there is a huge competition for land in urban areas (i.e. allocation of land to residential vs. food production purposes). Thus, in Johannesburg and Cape Town, mini-gardens and community gardens have been seen as a solution to the land access issue. As a consequence, individuals fill tires with arable soil so that they can grow vegetables. In addition, a garden association is another solution that can help face the land challenge whereby land in community churches, schools, community clinics and community halls can be used to grow crops. There is a pilot study conducted in Cape Town on rooftop gardening. This is yet another way that researchers are bringing workable solutions that can help promote home gardening among households.

Level of education was acknowledged to be another limitation. This means that adequate training and workshops are needed to help improve the practice of home gardens. There is a great need for scientific knowledge to cope with challenges such as climate change. Of all the households visited, the elderly were the ones identified to be engaged in home gardening more than the youth. These people mentioned that they make use of indigenous knowledge. Therefore, agricultural advisors need to visit urban areas more frequently than rural areas and disseminate information and deliver training that these households need to improve own food production. Also, this study opened room for the recording of indigenous knowledge these households rely upon, and for finding a way to integrate this kind of knowledge with scientific knowledge so that it can be used simultaneously without any challenges. Thus, a strong link between researchers, communities and government is essential in carrying out such activities. In addition to challenges, it can also provide workable solutions that are realistic rather than just theoretical.

\section{ACKNOWLEDGEMENTS}

Much gratitude and appreciation goes to the University of Fort Hare, Human Sciences Research Council and the Alice Town community for the support and allowing the author to conduct such a study.

\section{REFERENCES}

Agbodigi, O. M., Adolor, E. B. (2013). Home gardens in maintenance of biological diversity. App. Sci. Rep., 1(1), 19-25. Retrieved June $18^{\text {th }} 2016$ from: https://pdfs.semanticscholar.org/9b58/e627e9699abd8bb1a4af517a96b9d9e87d07.pdf

Ashby, J. (1981). New models of agricultural research and extension: The need to integrate women. In: B. C. Lewis (ed.), Invisible farmers: Women and the crisis in agriculture, Washington DC: USAID.

Bagson, E., Wuleka Kuuder, C.-J. (2013). Assessment of a Smallscale Irrigation Scheme on Household Food Security and Leisure in Kokoligu; Ghana. Res. Humanit. Soc. Sci., 3. Retrieved from: https://www.researchgate.net/ publication/281271410_Assessment_of_a_Smallscale_Irrigation_Scheme_on_Household_Food_Security_and Leisure_in_Kokoligu_Ghana

Baiphethi, M. N., Jacobs, P. T. (2009). The Contribution of Subsistence Farming to Food Security in South Africa. Agrekon., 48(4), 342-346.

Baiyegunhi, L. J. (2014). Determinants of rainwater harvesting technology (RWHT) adoption for home gardening in Msinga, KwaZulu-Natal, South Africa. Discip. Agric. Econ., 41(1), 33-40.

Drimie, S., Ruysenaar, B. (2010). The Integrated Food Security Strategy of South Africa: An institutional analysis. Agrekon, 49(3), 316-333.

FAO (Food and Agricultural Organization) (1996). Rome Declaration on World Food Security and World Food Summit Plan of Action. World Food Summit 13-17 November 1996, Rome.

FAO (Food and Agriculture Organisation) (2012). Food in Cities. Retrieved July 22 2016 from: http://www.fao.org/ tempref/docrep/fao/012/ak824e/ak824e00.pdf

FAO (Food and Agriculture Organisation) (2018). Urban agriculture. Retrieved May $18^{\text {th }} 2018$ from: http://www.fao. org/urban-agriculture/en

Ferdous, P. (2016). Urban agriculture and ecological citizenship in Philadelphia. Local Env., 15(6), 581-590.

Gichunge, C., Kidwaro, F. (2014). Refugees and cultivating new roots in urban communities. J. Inter. Rel., 20(3), 77-86. Retrieved September $3^{\text {rd }} 2017$ from: http://www. sirjournal.org/research/2016/2/24/cultivating-new-rootsin-urban-communities

Gujarati, D. N. (2003). Basic Econometrics (4 $4^{\text {th }}$ Ed.). New York: McGraw Hill.

Kleinbaum, D. G. (1994). Logistic regression: A self-learning text. New York: Springer-Verlag. 
Matebeni, F. (2018). Measuring rural household food security in the Nkonkobe local Municipality, Eastern Cape Province of South Africa. Master of Science Dissertation, University of Stellenbosch.

Mcata, B. (2013). The role of home gardens in enhancing food security in rural and urban areas: A case study of Nkonkobe Municipality, Eastern Cape - South Africa. Master of Science Dissertation, University of Fort Hare.

Monde, N., Fraser, G., Botha, J. J., Anderson, K. (2006). Making home gardening a viable option in rural areas of South Africa: The case study of Guquka and Khayalethu in central Eastern Cape. Retrieved August $11^{\text {th }} 2017$ from: http://www.uwsp.edu/cnr/gem/Conference\%20Procceedings/Track5Papers/Monde\%20Track5\%20EMSU\%20 paper\%20FinalComplete.pdf

Montshwe, D. B. (2006). Factors affecting participation in mainstream cattle markets by small-scale cattle farmers in South Africa. Master of Science Dissertation, University of Free State.

Mqikela, N. (2014). The Impact of Land and Agrarian Reforms On Poverty Alleviation: Lessons From The Jay Dee Rovon Workers Trust And Mon Desire In Joubertina, Eastern Cape-South Africa. Publishing Master of Agriculture Dissertation. University of Fort Hare.

Mtolo, A. (2016). Food security and coping strategies of an urban community in Durban. Master Of Applied Science Dissertation, Durban University Of Technology.

Muchara, B. (2010). Analysis of food value chain in smallholder crop and livestock enterprises in Eastern Cape Province of South Africa. MSc Thesis (Unpublished). University of Fort Hare.

RDAR (Rural Development and Agrarian reform) (2016). Agricultural and Development potential in the Eastern Cape. Retrieved July 15, 2018 from: http://www.erln.co.za/images/jevents/57d67fc3564611.19113462.pdf

Rubin, M. (2011). Reducing the vulnerability of urban Slums Dwellers in the Southern African Region to the Impact of Climate Change and Disasters. Retrieved May 24, 2018 from: http://www.urbanlandmark.org.za/downloads/concept_paper_cc_vulnerability.pdf

Sanyé-Mengual, E., Anguelovski, I., Oliver-Solà, J., Montero, J. I., Rieradevall, J. (2016). Resolving differing stakeholder perceptions of urban rooftop farming in Mediterranean cities: promoting food production as a driver for innovative forms of urban agriculture. Agric. Human Values, 33(1), 11120. Retrieved May $18^{\text {th }} 2018$ from: https://link.springer. com/article/10.1007/s10460-015-9594-y

Seti, S. (2003). Subsistence Gardening for Food Security: A Case Study of Three Townships in Grahamstown, Eastern Cape Province. Retrieved May $22^{\text {nd }} 2010$ from: http:// docs.google.com/viewer? $\mathrm{a}=\mathrm{v} \& \mathrm{q}=$ cache:qkkBVWyju_0J: www.fhiser.org.za/Workingpapers/53Seti.pdf

Stats SA (Statistics South Africa) (2017). Poverty Trends in South Africa: An examination of absolute poverty between 2006 \& 2015. Retrieved June $18^{\text {th }} 2018$ from: http:// www.statssa.gov.za/?p=10341

Tacoli, C., McGranahan, G., Satterthwaite, D. (2015). Urbanization, rural-urban migration and urban poverty. Retrieved June 18 2018 from: https://www.iom.int/sites/default/ files/our_work/ICP/MPR/WMR-2015-Background-Paper-CTacoli-GMcGranahan-DSatterthwaite.pdf

Tynsong, H., Tiwari, B. K. (2010). Plant Diversity in the Home gardens and their Significance in the Livelihoods of War Khasi Community of Meghalaya North-east India. Retrieved April 11 2016 from: http://www.krepublishers. com/02-Journals/JBD/JBD-01-0-000-10-Web/JBD-011-000-10-Abst-PDF/JBD-01-1-001-10-006-Tynsong-H/ JBD-01-1-001-10-006-Tynsong-H-Tt.pdf

UNISDR (2015). Poorly planned and managed urban development. Retrieved June $18^{\text {th }} 2018$ from: https://www. preventionweb.net/risk/poorly-planned-managed-urbandevelopment

Young, J. (2013). Investing in the Eastern Cape. Retrieved June $18^{\text {th }} 2016$ from: https://www.brandsouthafrica.com/ investments-immigration/business/investing/opportunities/investing-in-the-eastern-cape 